九州大学学術情報リポジトリ

Kyushu University Institutional Repository

Comprehensive Analysis of Wound-inducible Genes from the Nicotiana glutinosa Leaves Using a Full-length cDNA Microarray

Kouzuma, Yoshiaki

Faculty of Agriculture, Graduate School Kyushu Unviersity

Tsutsumi, Yusuke

Faculty of Agriculture, Graduate School Kyushu Unviersity

Abe, Masumi

Faculty of Agriculture, Graduate School Kyushu Unviersity

Hayashi, Takeshi

Faculty of Agriculture, Graduate School Kyushu Unviersity

他

https://doi.org/10.5109/4677

出版情報：九州大学大学院農学研究院紀要. 50 (2)，pp.635-648，2005-10-01. Faculty of Agriculture, Kyushu University

バージョン：

権利関係 : 


\title{
Comprehensive Analysis of Wound-inducible Genes from the Nicotiana glutinosa Leaves Using a Full-length cDNA Microarray
}

\author{
Yoshiaki KOUZUMA ${ }^{1}$, Yusuke TSUTSUMI ${ }^{1}$, Masumi ABE ${ }^{1}$, Takeshi HAYASHI', \\ Kazumasa HADA ${ }^{1}$, Keigo UEHASHI ${ }^{2}$, Yukiko SHIMADA ${ }^{2}$, \\ Kosuke TASHIRO ${ }^{2}$, Satoru KUHARA ${ }^{2}$ \\ and Makoto KIMURA ${ }^{1 *}$
}

Laboratory of Biochemistry, Faculty of Agriculture, Graduate School, Kyushu University, Hakozaki 6-10-1 Higashi-ku, Fukuoka 812-8581, Japan

(Received June 30, 2005 and accepted July 26, 2005)

\begin{abstract}
Wound-inducible gene expression in the the Nicotiana glutinosa leaves was studied by using a microarray with 9600 full-length cDNAs. As a result, 86 genes were identified as wound-inducible genes in the $N$. glutinosa leaves, including those encoding defense related proteins, such as heat shock proteins, glutathione S-transferase, ascorbate peroxidase and nonspecific lipid-transfer proteins. Among 86 genes, 15 genes including 11 hypothetical protein genes and 1 unknown protein genes encode unknown functional proteins. Although the translational products of these genes have not been characterized, they are potential candidates for defense-related proteins toward wounding. The cluster analysis classified the genes into 6 groups on the basis of their expression patterns. It is likely that genes clustered in the same groups may be co-regulated by common transcriptional factors and also translational products belonging to the same clusters may share common functions in defense response to wounding.
\end{abstract}

\section{INTRODUCTION}

Since plants are continuously exposed to various environmental and biological stresses, they have evolved a number of mechanisms to cope with different biotic and abiotic stresses. Among stresses, a mechanical wounding followed by pathogen attacks is a continual threat to the survival of plants. Once wounded and pathogen invaded, plants induce various defense-related gene expressions in a time window between a few minutes to several hours to produce the substances that restore damaged tissues and also inhibit growth of pathogens. The first identified wound-inducible defense proteins are proteinase inhibitors I and II from potato and tomato (Graham et al., 1986; Ryan, 1990). To date, a number of defense-related genes have been identified in various plants; some of these defense-related genes encode transcription factors, osmotin, and several enzymes, such as proteases, chitinases, and peroxidases (Reymond and Farmer, 1998; De Bruxelles and Roberts, 2001; Jameson and Clarke, 2002). Although a vast amount of information about defense-related genes as well as chemical signals for a signal transduction have accumulated for diverse plant species, a detailed network of defense-related genes in a

\footnotetext{
1 Laboratory of Biochemistry, Faculty of Agriculture, Graduate School, Kyushu University

${ }^{2}$ Laboratory of Molecular Gene Technics, Faculty of Agriculture, Graduate School, Kyushu University

* Corresponding author (E-mail: mkimura@agr.kyushu-u.ac.jp)
} 
give plant has not been elucidated. To this end, it is essential to be aware of extensive changes of the gene expression that occur in a given plant under wounding and pathogen attacks.

The DNA microarray has recently been used to monitor a global gene expression in response to several stresses in higher plants. In the analysis, more than 10000 genes of interest organism could be simultaneously analyzed in terms of their expression profiles. In Arabidopsis, Seki et al. (2001; 2002) monitored expression of genes in response to cold, drought, and salt stress. Gong et al. (2001) used 84 salt-regulated cDNAs to profile transcription of wild type and the salt-hypersensitive mutant sos3 and Fowler and Thomashow (2002) profiled transcripts responding to cold acclimation. In rice (Dubouzet et al., 2003) and barley (Oztur et al., 2002), cDNA microarray was used to study transcriptional profiling in response to salt and drought stress. In maize kernels and immature ears, Zinselmeier et al. (2002) used cDNA microarrays to monitor expression of 384 genes in response to shade stress and used oligonucleotide microarrays to examine expression of 1,502 genes in response to water stress. These studies have provided new insights into gene expression involved in stress responses at a genomic level and are contributing to understanding of functions of the responding genes. Furthermore, the cDNA microarray analysis is a useful method for efficiently exploring the functions of uncharacterized genes in addition to known genes by relating the expression pattern of one gene to those of others.

Nicotiana glutinosa is a diploid tobacco plant and displays TMV-resistance mediated by $N$-gene. The $N$-gene, cloned from tobacco, is a member of the Toll-IL-1 receptor homology region (TIR)-nucleotide binding site (NBS)-leucine-rich repeat region (LRR) class of $R$ genes and confers resistance to the viral pathogen TMV (Whitham et al., 1994). That is, TMV-infection at $25^{\circ} \mathrm{C}$ causes hypersensitive cell death in leaves. In contrast, when $N$. glutinosa infected with TMV was kept at $35^{\circ} \mathrm{C}$, no local lesions were formed on the leaves, but systemic infection occurred. These observations led us to the expectation that comparison of the gene expression in response to TMV-infection at $25^{\circ} \mathrm{C}$ and $35^{\circ} \mathrm{C}$ would provide essential genes responsible for TMV resistance of $N$. glutinosa. For an initial step for this study, we have prepared the $N$. glutinosa full-length cDNA microarray containing $9600 \mathrm{cDNAs}$ and first studied gene expression dynamics in mock-inoculated (mechanical wounding) N. glutinosa leaves. In this paper, we described identification and the cluster analysis of wound-inducible genes in the N. glutinosa leaves.

\section{MATERIALS AND METHODS}

\section{Plant material, stress treatments and RNA isolation.}

The plants ( $N$. glutinosa) were germinated and grown in soil pots in a greenhouse of Kyushu University under natural lighting at $25^{\circ} \mathrm{C}$ for 1.5 months. The $N$. glutinosa leaves were dusted with Carborundum ( 600 mesh) and rubbed with cotton pads moistened with

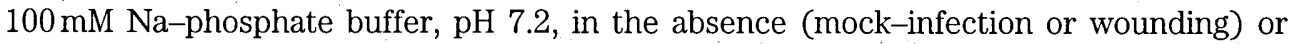
presence of TMV $(10 \mu \mathrm{g} / \mathrm{ml})$ (TMV-infection). After $0.5 \mathrm{~h}, 24 \mathrm{~h}$, and $48 \mathrm{~h}$, leaves were harvested, frozen in liquid nitrogen, and stored at $-80^{\circ} \mathrm{C}$ until use. The total leaf RNA was extracted by the method of Shirzadegan et al. (1991) 


\section{Preparation of full-length cDNA library.}

The oligo-capping cDNA was prepared by the method of Suzuki and Sugano (2001), as follows. Ten $\mu$ g of poly(A) ${ }^{+}$RNA purified by utilizing Oligotex ${ }^{\mathrm{TM}}-\mathrm{dT} 30<$ Super $>$ (TAKARA BIO) from $N$. glutinosa leaves were treated with 1.2 unit of bacterial alkaline phosphatase (BAP: TAKARA BIO) in $220 \mu \mathrm{l}$ of $100 \mathrm{mM}$ Tris- $\mathrm{HCl}(\mathrm{pH} 8.0), 5 \mathrm{mM} 2$-mercaptoethanol with 100 unit of RNasein (Promega) at $37^{\circ} \mathrm{C}$ for $40 \mathrm{~min}$. After extraction with phenol/chloroform/isoamylalcol (24/25/1) twice and ethanol precipitation, the poly(A) ${ }^{+}$RNA was treated with 20 units of tobacco acid pyrophosphatase (TAP: Nippon gene) in $100 \mathrm{ml}$ of $50 \mathrm{mM}$ sodium acetate (pH 5.5), $1 \mathrm{mM}$ EDTA, $5 \mathrm{mM}$ 2-mercaptoethanol with 100 units of RNasein at $37^{\circ} \mathrm{C}$ for $45 \mathrm{~min}$. After extraction with phenol/chloroform/isoamylalcol (24/25/1) and ethanol precipitation, the poly(A) ${ }^{+}$RNA (4 6 $\left.\mu \mathrm{g}\right)$ treated with BAP and TAP were ligated with $0.5 \mathrm{mg}$ of RNA oligonucleotide, 5'-GAG ACG GAU CCU AAA CAA UUA ACC CUC AAA-3' using 50 units of $\mathrm{T}_{4}$ RNA ligase (TAKARA BIO) in $100 \mu \mathrm{l}$ of $50 \mathrm{mM}$ Tris- $\mathrm{HCl}$ (pH 7.5), $5 \mathrm{mM} \mathrm{MgCl}_{2}, 5 \mathrm{mM}$ 2-mercaptoethanol, $0.5 \mathrm{mM}$ ATP, $25 \%$ PEG8000 with 100 units of RNasein at $20^{\circ} \mathrm{C}$ for $16 \mathrm{~h}$. After removing unligated RNA oligonucleotide by extraction with phenol/chloroform/isoamylalcol and ethanol precipitation, first-stranded cDNA was synthesized with AMV reverse transcriptase using 5'-GGC CAC GCG TCG ACT AGT ACT TTT TTT TTT TTT TTT T-3' in $50 \mu$ with $2 \sim 4 \mu \mathrm{g}$ of oligo-capped poly (A) ${ }^{+} \mathrm{RNA}$ at $42^{\circ} \mathrm{C}$ for $60 \mathrm{~min}$. After first strand synthesis, RNA was degradated in $15 \mathrm{mM} \mathrm{NaOH}$ by incubating at $65^{\circ} \mathrm{C}$ for $60 \mathrm{~min}$. The cDNA made from $0.7 \mathrm{mg}$ of oligo-capped poly (A) ${ }^{+}$RNA was amplified by PCR with Ex Taq polymerase (TAKARA BIO) using forward primer, 5'-GAG ACG GAT CCT AAA CAA TTA ACC CTC AAA-3' and back primer, 5'-GGC CAC GCG TCG ACT AGT AC-3'. Amplification cycles were 10 cycles at $94^{\circ} \mathrm{C}$ for $1 \mathrm{~min}, 58^{\circ} \mathrm{C}$ for $1 \mathrm{~min}$, and $72^{\circ} \mathrm{C}$ for $10 \mathrm{~min}$. The PCR products were separated by an agarose gel electrophoresis and those longer than $700 \mathrm{bp}$ were isolated and ligated into the $\mathrm{pGEM}^{\mathrm{TM}}-\mathrm{T}$ Easy vector (Promega). The ligation mixtures thus obtained were stored at $-80^{\circ} \mathrm{C}$ until use. For cDNA cloning, the mixtures were used for transformation into $E$. coli JM109 strain.

\section{Amplification of cDNA insert.}

Discretionary cDNAs (9600 clones) were grown in twenty five 384-well microtiter plates at $37^{\circ} \mathrm{C}$ for $16 \mathrm{~h}$. The cDNAs were amplified by PCR using cultures as template and same primers as double-stranded cDNA amplification. Amplifications were done for 35 cycles at $94^{\circ} \mathrm{C}$ for $1 \mathrm{~min}, 55^{\circ} \mathrm{C}$ for $1 \mathrm{~min}$, and $72^{\circ} \mathrm{C}$ for $1 \mathrm{~min}$. The PCR products were precipitated in 2-propnanol, then resuspended at $\sim 2 \mathrm{mg} / \mathrm{ml}$ in TE buffer, mixing 20 times using Multimek 96/384 Multi-Channel Pipettor (Beckman Coulter).

\section{Microarray preparation.}

The PCR products were arrayed from 384-well microtiterplate onto a microslide glass (Matsunami, Japan) using the microarray stamping machine SPBIO (Hitachi software Engineering Co., Ltd., Japan). The printed slides were dried and subjected to UV cross-linking $(600 \mathrm{~mJ} \times 100)$. The slides were rocked in $70 \mathrm{mM}$ succinic anhydride $/ 0.1 \mathrm{M}$ borate buffer dissolved in 1-methyl-2-pyrrolidone for $30 \mathrm{~min}$ and then rocked in Milli-Q water for $30 \mathrm{~s}$ thrice vigorously. The slides were transferred into the boiling Milli-Q water for $3 \mathrm{~min}$ and then ice-cold ethanol for $5 \mathrm{~min}$. The slides were air-dried and used for 
further hybridization step.

\section{Preparation of probes.}

Total RNAs from healthy leaves or treated leaves $(10 \mathrm{~min}, 30 \mathrm{~min}, 1 \mathrm{~h}, 2 \mathrm{~h}, 4 \mathrm{~h}, 8 \mathrm{~h}$, $12 \mathrm{~h}, 24 \mathrm{~h}, 48 \mathrm{~h}$, and $72 \mathrm{~h}$ after treatment) were reverse-transcribed using Powerscript (Clontech) in the presence of amino-allyl dUTP (Sigma). Each reaction was performed in a $40 \mu \mathrm{l}$ volume containing $50 \mu \mathrm{g}$ of total RNA, $2 \mu \mathrm{g}$ of oligo (dT) 18 mer (New England Biolabs), $0.5 \mathrm{mM}$ each for dATP, dCTP, dGTP, and $0.2 \mathrm{mM}$ dTTP, $0.3 \mathrm{mM}$ amino-allyl dUTP (Sigma), 10 units of RNasein, $10 \mathrm{mM}$ DTT, and $2 \mu \mathrm{l}$ of Powerscript reverse-transcriptase in Powerscript first-strand buffer. After incubation at $42^{\circ} \mathrm{C}$ for $1 \mathrm{~h}, 2 \mu \mathrm{l}$ of Powerscript was added and the mixture was further incubated for $1 \mathrm{~h}$. The reaction was stopped by addition of $50 \mu \mathrm{l}$ of $100 \mathrm{mM}$ EDTA and RNA in the reaction mixture was degraded by adding $20 \mu \mathrm{l}$ of $1 \mathrm{M} \mathrm{NaOH}$ at $60^{\circ} \mathrm{C}$ for $30 \mathrm{~min}$. The reaction mixture was neutralized by addition of $50 \mu \mathrm{l}$ of $1 \mathrm{M}$ Tris- $\mathrm{HCl}(\mathrm{pH} 7.5)$. The synthesized cDNA was purified by size-exclusion spin column (microcon30, Amicon) and dissolved in $20 \mu \mathrm{l}$ of $50 \mathrm{mM}$ $\mathrm{NaHCO}_{3}$. Labeling reactions with Cy5 monofunctional dye (Amersham Biosciences) for control samples (healthy leaves) or Cy3 monofunctional dye for treated samples (wounded leaves) were performed in the dark at room temperature for $60 \mathrm{~min}$. After blocking by $\mathrm{NH}_{2} \mathrm{OH}$, the Cy3-labeled and Cy5-labeled probes were pooled in a same tube and incubated at room temperature for $15 \mathrm{~min}$. The excess reagents were removed by PCR purification kit (Qiagen). The labeling cDNA probes were checked by an agarose gel electrophoresis and used for hybridization.

\section{Hybridization reaction and microarray analysis.}

Before hybridization, the cDNA solution $(40 \mu \mathrm{l})$ containing $5 \times \mathrm{SSC}$ and $0.5 \%$ SDS was heated at $65^{\circ} \mathrm{C}$ and then used for microarray analysis. The microarrays were placed in hybridization cassette and Milli-Q water $(7 \mu \mathrm{l})$ was placed inside each chamber before sealing and then incubated for $10 \sim 20 \mathrm{~h}$ at $60^{\circ} \mathrm{C}$. After incubation, the microarrays were sequentially washed thrice for $5 \mathrm{~min}$ in $2 \times \mathrm{SSC}-0.2 \%$ SDS, thrice for $5 \mathrm{~min}$ in $0.2 \times$ SSC- $0.2 \%$ SDS, thrice at $60^{\circ} \mathrm{C}$ for $20 \mathrm{~min}$ in $0.2 \times$ SSC- $0.2 \%$ SDS, thrice for $5 \mathrm{~min}$ in $0.2 \times$ SSC- $0.2 \%$ SDS, four times for $10 \mathrm{~s}$ in $0.2 \times \mathrm{SSC}$, and finally twice in $100 \%$ ethanol. Microarrays were dried by centrifugation at $800 \mathrm{rpm}$ for $3 \mathrm{~min}$, and then scanned with Bio-imaging analyzer BAS-5000 (Fuji Film). The image files were analyzed using Arrayvison software (Imaging Research Inc.).

\section{Data analysis.}

A difference in fluorescent strength between Cy3 and Cy5 causes a bias of the expression quantify ratio. The signal intensities of duplicate spots on an array were therefore normalized by locally weighted linear regression analysis (LOWESS) (Shirzadegan et al., 1991). Then, the average intensity ratio (Cy3/Cy5) followed by $\log _{2}$ (Cy3/Cy5) was calculated. Furthermore, cDNA clones showing a signal value lower than 10000 in both Cy3 and Cy5 channels were eliminated for analyses. For screening wound-inducible genes, the median and standard deviation (SD) of $\log _{2} \mathrm{Cy} 3 / \mathrm{Cy} 5$ were calculated, and then, the cDNA clones with expression ratio $\left(\log _{2} \mathrm{Cy} 3 / \mathrm{Cy} 5\right)$ greater than median $+2 \mathrm{SD}$ in at least one time-course point were selected as wound-inducible genes. 
All of the processed data then were subjected to the self-organizing map algorithm followed by complete linkage hierarchical clustering of microarray genes, as described by Eisen et al. (1998) We used the default options of hierarchical clustering using the uncentred correlation similarity metric.

\section{cDNA sequencing analysis for microarray.}

The nucleotide sequences of the cDNAs selected as wound-inducible genes were determined using the dye terminator cycle sequencing method (CEQ2000 Dye Terminator Cycle Sequencing with Quick Start Kit; Beckman Coulter) with a DNA sequencer CEQ2000XL (Beckman Coulter). Homology search was performed with the Gen-Bank/EMBL database using the BLAST program (Julich, 1995).

\section{Validation of microarray data by reverse transcription PCR.}

The expression patterns of wound-inducible genes were confirmed by reverse transcription PCR (RT-PCR). The RT-PCR procedure was done as follows. Total RNAs $(1 \mu \mathrm{g})$ extracted from wound treatment leaves $(30 \mathrm{~min}, 2 \mathrm{~h}, 8 \mathrm{~h}, 24 \mathrm{~h}$ and $48 \mathrm{~h}$ after treatment) were reverse-transcribed using Powerscript (Clontech) with oligo d(T) 18 primer (Biolabs). The cDNA mixture was amplified by LA-Taq (TAKARA BIO) with the following gene-specific primer pairs: NgA5004-forward primer, 5'-CATATGGGAGGAGGAACAGAAGCTTTTCCA-3'; NgA5004-reverse primer, 5'-CTCGAGACAAGCTTTAACGGAAGGGGTGGT-3'; NgC6193-forward primer, 5'-ATGGAATTGGCTGGCAAGATTGCATGTTTT-3'; NgC6193-reverse primer, 5'-CTGGACCTTGGACCAGTCAGTGGAGGGGCT-3'; NgB1164-forward primer, 5'-TGTGGGTGCTGTTGGGCATTTTCTGCAGTA-3'; NgB1164-reverse primer, 5'-ATCTATTGCCACCGAAACAGGTTGATTAGC-3'; rRNA-forward primer, 5'-TCTCGGCTCTCGCATCGATGAAGAACGTAG-3'; rRNA-reverse primer, 5'-GCGGGCGGGGGCGACGCGATGCGTGACGCC-3'. The samples were first denatured by heating at $94^{\circ} \mathrm{C}$ for $2 \mathrm{~min}$ and then incubated for 25 cycles at $94^{\circ} \mathrm{C}$ for $30 \mathrm{~s}, 60^{\circ} \mathrm{C}$ for $30 \mathrm{~s}$, and $72^{\circ} \mathrm{C}$ for $1.5 \mathrm{~min}$. The samples were finally incubated for $5 \mathrm{~min}$ at $72^{\circ} \mathrm{C}$. The amplified products were analyzed by $1 \%$ agarose gel electrophoresis.

\section{RESULTS AND DISCUSSION}

\section{Preparation of the $N$. glutinosa cDNA Microarrray}

We constructed full-length cDNA libraries from the $N$. glutinosa leaves which were non-treated or wounded followed by TMV-infection, as described under Materials and methods. We unintentionally selected 9600 cDNA clones, amplified them by PCR and arrayed onto glass slides, as described under Material and methods. Judging from the sequence analyses of $100 \mathrm{cDNA}$ clones, we estimated that approximately 4000 unique clones were included in the selected cDNA clones. The average frequency of full-length cDNA clones in the library was about $50 \%$.

In order to evaluate the cDNA microarray as well as the method for data normalization, the total RNA extracted from wounded leaves was split in two identical aliquots, to exemplify mRNAs from control and treated leaves. Two populations of single stranded cDNAs were generated from the two aliquots and labeled with Cy3 and Cy5 fluorophores, 
A

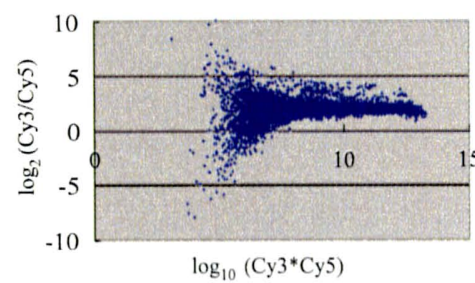

B

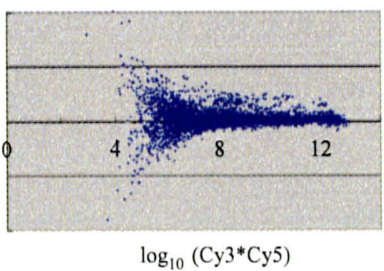

$\mathrm{C}$

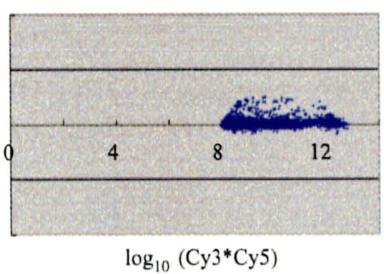

Fig. 1. Normalization of the Data obtained by Microarray analysis

A, An R-I plot displays the $\log _{2}(\mathrm{Cy} 3 / \mathrm{Cy} 5)$ ratio for each element on the array as a function of the $\log _{10}\left(\mathrm{Cy} 3{ }^{*} \mathrm{Cy} 5\right)$ product intensities and can reveal systematic intensity-dependent effects in the measured $\log _{2}(\mathrm{Cy} 3 / \mathrm{Cy} 5)$ values. B, Application of local lowess can correct for both systematic variation as a function of intensity and spatial variation between spotting pens on a cDNA microarray. C, Normalization data were obtained by elimination of the signal values lower than 10,000 of genes $\left(\log _{10} \mathrm{Cy} 3 / \mathrm{Cy} 5<\right.$ $8)$.

respectively. The two samples of labeled cDNA were simultaneously hybridized to the microarray, and the data were evaluated as described under Materials and methods. In this experiment, each transcript is equally abundant in the two samples. Hence a $\log _{2} \mathrm{Cy} 3 / \mathrm{Cy} 5$ signal ratio of 0 should ideally result for each spot in the microarray. As given in Fig. 1A, the R-I plot calculated with law data shows a slight shift of signal intensity ratios between Cy3 and Cy5 from $\mathrm{x}$ axis. This result suggested different fluorescent strengths between $\mathrm{Cy} 3$ and Cy5 or different background levels of cDNAs dependent on the spotting positions in the microarray. Then, all data were normalized by LOWESS so that signal ratios of almost all data were replicated to $\mathrm{x}$ axis (Fig. 1B). In addition, we eliminated data whose signal values were lower than $10,000\left(\log _{10} \mathrm{Cy} 3 / \mathrm{Cy} 5<8\right)$. As a result, almost all data were approximate around the $\mathrm{x}$ axis, indicating the dependability of the $N$. glutinosa cDNA microarrray for further analyses by normalization and elimination of low fluorescence intensity clones (Fig. 1C).

\section{Screening and Identification of Wound- inducible Genes}

For studying of a temporal program of transcription occurred in the $N$. glutinosa leaves in response to wounding, the $N$. glutinosa leaves at ten time points $(10 \mathrm{~min}$, $30 \mathrm{~min}, 1 \mathrm{~h}, 2 \mathrm{~h}, 4 \mathrm{~h}, 8 \mathrm{~h}, 12 \mathrm{~h}, 24 \mathrm{~h}, 48 \mathrm{~h}$, and $72 \mathrm{~h}$ ) up to $72 \mathrm{~h}$ after wound-treatment were detached and mRNA was purified therefrom. The cDNA made from each sample was labeled with the fluorescent dye Cy3 and mixed with a reference probe, consisting of cDNA made from healthy plants and labeled with the second fluorescent dye, Cy5. The two populations of labeled cDNAs were simultaneously hybridized with the cDNA microarray. Then, they were scanned by two separate laser channels for Cy3 and Cy5 emissions from DNA elements. After scanning fluors, the signal intensity for each cDNA was integrated to calculate the ratios of the fluorescence intensities of two probes. We performed ten separate hybridizations to monitor changes in transcripts in comparison 
with those of healthy plants at ten time points. To assess the reproducibility of the microarray analysis, the hybridizations were performed twice. The hybridization of different microarrays with the same mRNA samples showed a good correlation. A pseudocolor image of the results obtained for one time point (60 min after wound-treatment) is shown in Fig. 2.

All microarrays were normalized and cDNAs showing signal values lower than 10000 were eliminated. A typical scatter plot of signal intensities and its normalization are presented in Fig. 3. The median and SD of the signal ratios were calculated for spots on each glass slide. The wound-inducible genes were selected from ten time points of microarray, described in Materials and methods, resulting in that 104 clones were selected for further study.

These cDNAs were partially sequenced and the sequence data were analyzed with the BLAST program. The results are summarized as given in Table 1. Eleven wound-inducible genes occurred in more than two clones; the gene encoding the homologue of chroloplast thiazole biosynthetic protein from Nicotiana tabacum (LaFayette et al., 1996) was the most abundant gene identified: 8 clones possessed the identical gene. In this analysis, 11 and 1 genes whose sequences had sequence similarities to those of hypothetical protein genes and unknown protein genes, respectively, were identified as wound-inducible genes. Further biochemical characterization of their translational products will define their functions in plant defense. As a result, 86 independent genes were identified as wound-inducible genes. The DNA sequences of all

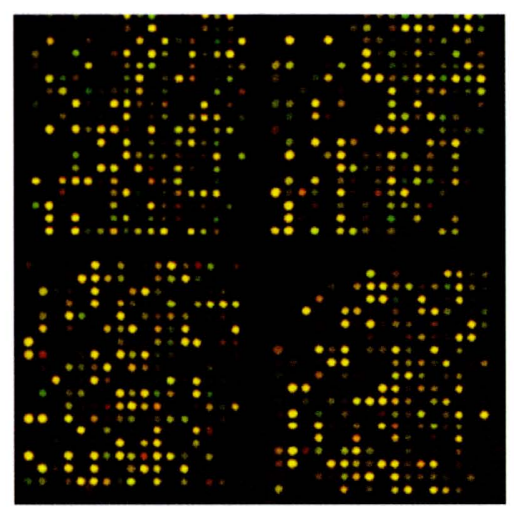

Fig. 2. Microarray Analysis of Gene Expression after Mechanical Wounding

A fluorescently labeled cDNA probe was prepared from mRNA isolated from control $N$. glutionosa leaves by reverse transcription in the presence of Cy3-dCTP. A second probe, labeled with Cy5-dCTP, was prepared from leaves that were mechanically wounded $(60 \mathrm{~min})$. After the simultaneous hybridization of both probes with cDNA microarray containing 9600 cDNA clones and scanning of the array, a pseudocolor image was generated. Genes induced or repressed after mechanical wounding are represented as green or red signals, respectively. Genes expressed at approximately equal levels between treatments appear as yellow spots. The intensity of each spot corresponds to the absolute amount of expression of each gene. 


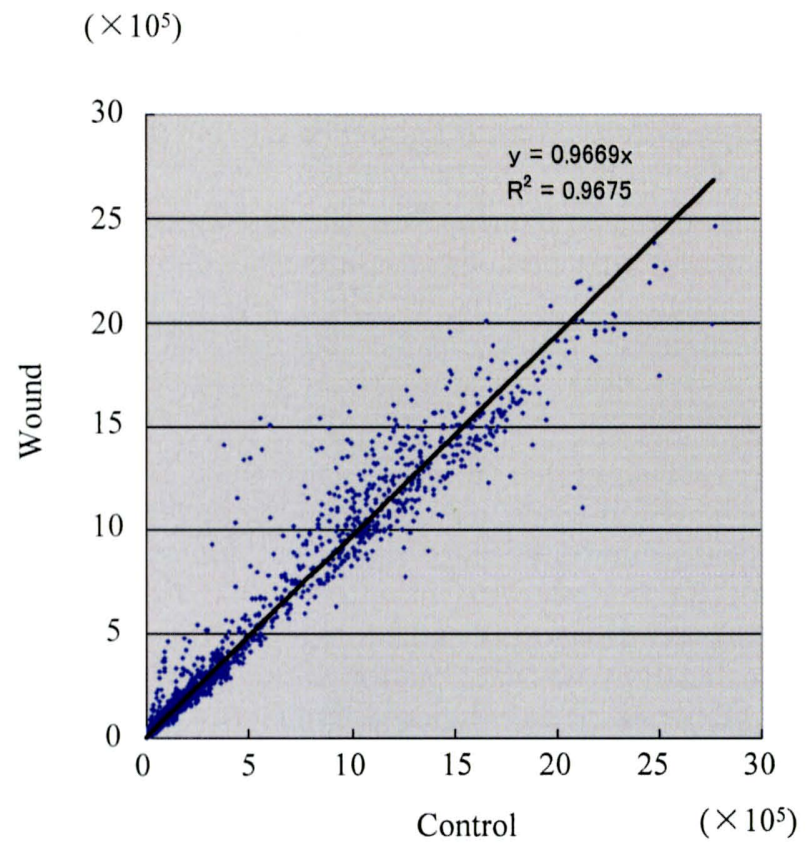

Fig. 3. A scatter plot of signal intensities for cDNAs on the microarray Normalized channel intensities for each cDNA clone on the microarray are plotted with signals from control and wounding on the $x$ and $y$ axes, respectively.

genes are listed at http://seika.ath.cx/cgi/tabako/.

\section{Confirmation of Gene Expression by Reverse Transcription PCR}

To corroborate the result obtained by the microarray analysis, RT-PCR was done for several selected genes using specific primers. Figure 4A shows representative results of RT-PCR for three wound-inducible genes. The transcripts of the gene NgA5004 began to accumulate $30 \mathrm{~min}$ after wounding, reached a maximum level within $2 \mathrm{~h}$, and then disappeared. The expression of the gene NgC6193 was significantly induced by wounding within $24 \mathrm{~h}$ and this increase was observed through $48 \mathrm{~h}$. In contrast, the expression of the gene NgB1164 was induced twice at $2 \mathrm{~h}$ and $24 \mathrm{~h}$ after wounding. These results were in a good agreement with the results obtained by the microarray analysis (Fig. 4B). Similar results were obtained for other selected genes (data not shown), demonstrating characteristic expression patterns of wound-inducible genes derived from the microarray analysis.

\section{Cluster Analysis of the Wound-inducible Genes}

We did cluster analysis to classify the 104 wound-inducible genes derived from the microarray experiment according to patterns of their gene expression, as described under 
Table 1. Wound-inducible Genes in the N. glutinosa Leaves.

\begin{tabular}{|c|c|c|c|c|c|c|}
\hline Gene number & Homologue & Accession number & Source & $\begin{array}{l}\text { Homologue in } \\
\text { Arabidopsis }\end{array}$ & Enzyme category ${ }^{\mathbf{a}}$ & Frequency \\
\hline $\mathrm{NgB2261}$ & Moteoulter chaperooe Fupgo-2 & AY368905 & Nlcotiana benthamiana & BT000717 & NE & 3 \\
\hline $\mathrm{NgCS2+6}$ & Molecular chaperose Bappo-1 & AY368906 & Lycopersicon esculentum & AY368906 & $\mathrm{NE}$ & 1 \\
\hline $\mathrm{NgC5076}$ & Beat chock proteis 90 & AB111810 & Onyza sativa & At5g52640 & $\mathrm{NE}$ & 1 \\
\hline $\mathrm{N}_{212} 254$ & Heat shock protein 90 & AYS19499 & Niconiane labacum & AY062832 & $\mathbf{N E}$ & 1 \\
\hline $\mathrm{N}_{z} \mathrm{BS} 279$ & Heat thock proteia 90 homologue T22A6.20 & T09882 & Arabidopsis thaliana & At4224190 & $\mathbf{N E}$ & $i$ \\
\hline $\mathrm{N}_{2} \mathrm{B6252}$ & Heat stack proteis 70 & A 2249330 & Cucumis sativens & $A 3_{2}: 2380$ & NE & 1 \\
\hline $\mathrm{NgC} 4367$ & Hent sbock protein 70 & AY253326 & Nicotiana tabacum & $A t 3 q 12580$ & NE & $i$ \\
\hline NeD1263 & Heat thock 70 protein & X13301 & Petunia $x$ hybrida & At502190 & NE & $i$ \\
\hline NEA6164 & $70 \mathrm{kDa}$ beet shock protein & AF479058 & Sandersonia surantitaca & AY035123 & $\mathrm{NE}$ & 1 \\
\hline NgCsolt & Cylocolic bear sthock 70 protetein & A 0033852 & Spinacia oleraceas & $\mathrm{AB}_{3} 122880$ & NE & i \\
\hline $\mathrm{N}_{2} \mathrm{D} 1230$ & 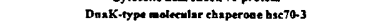 & Q40151 & Lycopersicon aculentem & AC069874 & $\mathbf{N E}$ & $\mathrm{t}$ \\
\hline NQBA166 & DasK-type adeacalar chaperane hsc70-3 & LA1253 & Lycopersicon esculentum & ALCR12SSO & NE & 2 \\
\hline $\mathrm{Ng} \mathbf{0 7 2 9 2}$ & DNAJ proteio & A 2299254 & Nicotiana tabacum & $A B_{3}+1110$ & NE & 1 \\
\hline NzAs040 & Hear sthock regante $70 \mathrm{kDa}$ protetio & $\mathbf{x} 54030$ & Lycopersicon esculentum & $A B_{\mathrm{g} i 25 s 0}$ & $\mathrm{ME}_{\mathbf{E}}(-1)(-1)$ & i \\
\hline $\mathrm{N}_{\mathrm{g} 11020}$ & APG prottio & AY114586 & Arabidopsis thatians & AY114586 & By & $i$ \\
\hline $\mathrm{N}_{2} \mathrm{BSta4}$ & Noospecific lipia-trnesser protein 2 precurnoer & Q03461 & Nicotians tabacum & $A 22_{23} 35440$ & NE & $i$ \\
\hline $\mathrm{NgC6}_{\mathrm{g}} \mathrm{C193}$ & Noaspecific tipit-transfer protein 2 precursor & 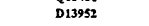 & Nicetians tabacum & At2zJBSSSO & $\mathrm{NE}$ & $\mathrm{t}$ \\
\hline $\mathrm{N}_{2} \mathrm{Ds} 196$ & Nomspec irse lipid-transfer protein 2 & S29227 & Nicatiana tabacum & At22 33540 & NE & $i$ \\
\hline NeBS071 & Noos-speeifine lipid transter protein & AFs25363 & Solanum fuberersum & A12 233540 & NE & $i$ \\
\hline NgBHG & Crsteine protease & AF242372 & lpomoesa beratatas & A A 5845850 & By & 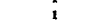 \\
\hline $\mathrm{NgC7073}$ & Cyrosolic secorbate peroxidase & 085912 & Nicotiana tabacum & $\mathbf{X} 59600$ & ox & 2 \\
\hline Nens242 & Ascerbate peroxidase & v15933 & Nicotiana labecum & $A+4,435000$ & ox & 2 \\
\hline $\mathrm{N}_{207272}$ & Aquaporib-fike protein & AF452015 & Petunia $\times$ hybrida & AY08755s & $\mathbf{N E}$ & 2 \\
\hline $\mathrm{N}_{2} \wedge 6243$ & Glatantiones S-transfernase TJ & AY007560 & Lycopersicon ecculentum & $A D_{22} 29420$ & $\operatorname{Tr}$ & $\mathrm{i}$ \\
\hline Nencest & DNA-bias cing protein tbz17 & D63951 & Nicosians tabacum & AF400620 & $\mathrm{NE}$ & $i$ \\
\hline $\mathrm{NgC1079}$ & MYB masaseription factor & AYS19516 & Arabidopsis thatiana & AYS19516 & $\mathbf{N E}$ & $i$ \\
\hline NeAsoos & Zine finger protein & AF139098 & Arabidopsis thelians & AF139098 & NE & i \\
\hline NeBB251 & Echyleaerespoustrve tran acriptiooal cosetivator & A 009246 & Lycopersicon eculentum & $A B_{2} 24500$ & $\mathbf{N E}$ & 1 \\
\hline NEA729S & Ethyleac-lorwing engymo EFE & $\mathbf{s} 41395$ & Nicotians tabacum & Attro5010 & ox & i \\
\hline $\mathrm{N}_{\mathrm{E}} \mathrm{D32S4}$ & GTP-bioding protein & AP002524 & Oryza sativa & Actigo2170 & NE & $i$ \\
\hline $\mathrm{N}_{2} \mathrm{B3} 3046$ & Cinetio prectursor & U20502 & Glycine max & At5607340 & $\mathbf{N E}$ & 2 \\
\hline NeAs136 & Thioredoxio H-type 1 & $\mathbf{x} 58527$ & Nicotiana tabacum & A(1219730 & ox & 2 \\
\hline $\mathrm{N}_{\mathrm{gB} 3142}$ & Abscisle streas Hpeabeg prottin 2 & $\mathbf{x 7 4 9 0 7}$ & Lycopersicon sectilentum & No homolog & $\mathbf{N E}$ & 1 \\
\hline Nen3264 & 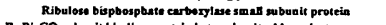 & AY220079 & Nicotiana tabacum & At5q3anio & Ly & 2 \\
\hline $\mathrm{N}_{2472+6}$ & RuBicO suban it binding-proted bect subuaih, chlaroplest precursor & M33600 & Brassica napuss & AC005223 & $\mathrm{L}_{9}$ & i \\
\hline NeA7149 & ADP ATP earrier protetia, altochon drial preceursor & $\mathbf{x} 62123$ & Solanum tuberosum & AY0.42814 & NE & i \\
\hline $\mathrm{N}_{2} \mathrm{B1266}$ & Chlorophyll ab bieding protetio 2, chloreplatet precectror & $\mathbf{x} 12735$ & Hordeum vulgere & At2805100 & NE & $i$ \\
\hline $\mathrm{N}_{2 \mathrm{BB271}}$ & Caloropbye al-bindiat protein type I & X64198 & Nicotians tabaccum & AY085893 & NE & $i$ \\
\hline $\mathrm{N}_{2} \mathrm{AS}=9 \mathrm{~S}$ & Chloroplast thesele biorgathetic protein & AY220080 & Nicotians tabsecum & Alsgs ST770 & $\mathbf{N E}$ & 8 \\
\hline $\mathrm{N}_{\mathrm{BB}} \mathrm{H} 1136$ & Pitl protrie & ABO13441 & Nkortiane tabacum & AC079605 & $\mathbf{N E}$ & 2 \\
\hline$N_{2} D_{215}$ & Clutumale decarboxylase & $\mathrm{AF} 020424$ & Nicosiane tabecum & Al2002010 & $\mathrm{L}_{\mathbf{J}}$ & $i$ \\
\hline $\mathrm{NgD3297}$ & Glukganale decerborytase & AF506366 & Nicotiana tabacum & $A 0: 02000$ & $\mathrm{Lg}$ & $\mathrm{i}$ \\
\hline $\mathrm{Ng}_{\mathrm{g}} 6124$ & RNA-biedieg dycioo-rike protein-1 & D16206 & Nicotiana sytreatris & s30148 & $\mathrm{NE}$ & 1 \\
\hline $\mathrm{NgBs144}$ & Glycina-rike RNA-binding protein & Di6204 & Nicotiana sylvestrits & AC007119 & $\mathbf{N \Sigma}$ & $i$ \\
\hline $\mathrm{Ne}_{\mathrm{r}} \mathrm{C} \cos 0$ & Plesddic ATP/ADP-traspoprer & Y10821 & Solanum tuberosum & At1 800300 & NE & i \\
\hline $\mathrm{NeC2}_{2} 240$ & 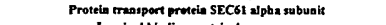 & AY093047 & Arabldopsis thatians & AY0930+7 & $\mathbf{N E}$ & 1 \\
\hline $\mathrm{Ne}_{\mathrm{g}} 6111$ & Luminal btadiaz protetia 4 prescursor & JQ1360 & Nicotians Labaccum & $A 158<2020$ & $\mathbf{N E}$ & i \\
\hline $\mathrm{Ng}_{8} \mathrm{Cs270}$ & L.uminas biadiag protecius 5 prectursor & Q03685 & Nicotiana tabacum & At5842150 & $\mathrm{NE}$ & $i$ \\
\hline$N_{t} D+101$ & nilootis the protein & A 3031956 & Nicotiane fabarum & MLIS5136 & $\mathrm{NE}$ & i \\
\hline $\mathrm{NeCS160}_{160}$ & SUMO E2 coojegatiog coxyma SCE1 & A5s80839 & Nicotians benthamiana & AL132977 & $\mathbf{L g}$ & $i$ \\
\hline $\mathrm{N}_{2} \mathrm{C}+28 \mathrm{~s}$ & 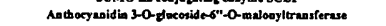 & AF 489109 & Dahlla variebills & $A_{13229577}$ & $\mathrm{Tr}$ & 1 \\
\hline NeBsits & 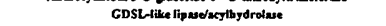 & AC128645 & Omye sative & AY072081 & $\mathbf{H y}$ & 1 \\
\hline NeCsi69 & Cell doegatioe protelia diminuto & AE017090 & Oryre sative & ABO23631 & NE & $i$ \\
\hline Nent227 & Acid phosphatstse & A 250282 & Hordeum vulgare subsp vulgare & AL 0355523 & Hy & $\mathbf{1}$ \\
\hline NaA7171 & Riberoued protein L34 & AC021043 & Arabidopsis thatians & AC021043 & $\mathbf{N E}$ & 1 \\
\hline $\mathrm{N}_{2} \mathrm{~N}_{23} 3 \mathrm{P}$ & Retrodeseat pol polyproteit & ACO004453 & Arabidopsis thationa & ACO04483 & Trrag & 1 \\
\hline NzDsess & Pbospholipid hy droperoxide zlutath looe perosidse & Q9FXs3 & Nlcotlana tabacum & At4\&11600 & $0 x$ & 1 \\
\hline NeA7120 & Eposide hydrol ase & Q41413 & Solanum tuberosism & At4g23280 & By & 1 \\
\hline $\mathrm{NZ}_{\mathrm{BS}} 192$ & NADP-Apetifitic iocitrnte dehydrogeanse & AB109115 & Lupinus albus & N1437268 & ox & i \\
\hline $\mathrm{Ng}_{2} \mathrm{COQH7}$ & Malto debydrozenase & AFo0:270 & Lycoperstcon esculentum & A15811670 & ox & $i$ \\
\hline $\mathrm{N}_{2} \mathrm{B7224}$ & Lethal lear spoet t-like protein & AF321984 & Lycopersican eculentum & v17347 & NE & 1 \\
\hline $\mathrm{N}_{2} 08190$ & 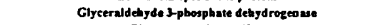 & AFs27779 & Solanum tuberosum & Attel3440 & ox & $i$ \\
\hline $\mathrm{N}_{2} \mathrm{B3} 167$ & 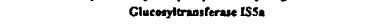 & T03747 & Nlcotiana fabacum & $A \mid 4 Q_{3} 3120$ & $\mathrm{Tr}$ & $i$ \\
\hline $\mathrm{N}_{2} \mathrm{D} 124$ & EEF13 protein & ABO32733 & Solanum melongene & At42929270 & $\mathrm{By}$ & $i$ \\
\hline$N_{2 D 1191}$ & Caffeic acia O-Methyltransferase II & AFt\$84252 & Nicotiana tabacum & A8013387 & $\mathrm{Tr}$ & $i$ \\
\hline $\mathrm{NgC8247}$ & C-L,7 sterol isomerases & $A_{11820050}$ & Arabidopsis thatians & $A+1 E_{2}^{20050}$ & 4 & 1 \\
\hline Nensing & Nplatubodin & Astzis11 & Nicoriana fabarcum & AL161540 & NE & $i$ \\
\hline Nans299 & 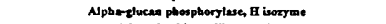 & A 40995 & Solanum muberosum & $A+33_{26970}$ & $\operatorname{Tr}$ & $i$ \\
\hline $\mathrm{N}_{8} \mathrm{C} 4236$ & Aden osine kbase-like protein & AY224510 & Onzes sativa & $A A_{3} 09820$ & $\operatorname{Tr}$ & $i$ \\
\hline $\mathrm{N}_{2} \mathrm{Bs} 193$ & AFt-CoA spothetase-fike proteio & AFS503771 & Arabidopsis thatians & AF503771 & $u_{\mathbf{g}}$ & $i$ \\
\hline 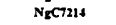 & \&A $\mathrm{K}$ germi io like protetin precursor & AB112080 & Nicotiana tabaccem & AY081576 & By & $i$ \\
\hline $\mathrm{N}_{2} \mathrm{B2} 2106$ & $21 \mathrm{~K}$ protetio precursor & Y11553 & Medicago sative subsp $x$ varias & AL096860 & $\mathrm{NE}$ & $\mathrm{I}$ \\
\hline $\mathrm{N}_{2} \mathrm{BB} 153$ & Water-treses indacible protetin & AFO10584 & Onye sative & No homoloz & NE & $i$ \\
\hline $\mathrm{NgCl}_{273}$ & Stressordated protein & US4704 & Phasedus vulgaris & $A 13805500$ & NE & $i$ \\
\hline $\mathrm{N}_{8} \mathrm{C} 2181$ & Unkeown protein & AY035092 & Arabidopsis thallana & AY035092 & & $i$ \\
\hline $\mathrm{N}_{2} \wedge 8243$ & Hypotetetical protein & A3Z15840 & Arabidopsis theliana & $A^{13} z+5840$ & & I \\
\hline $\mathrm{N}_{8} \mathrm{B3} 054$ & Bgpoctelical protein & A21001100 & Arabididopsis thatiana & $A 12=01100$ & & $i$ \\
\hline NgBA277 & Eypotheticen protein & A1078467 & Arabidopsis thaliana & AL 078467 & & $i$ \\
\hline $\mathrm{N}_{\varepsilon} \mathrm{BS} 153$ & Hypotetical protein & $\mathrm{A}_{22} 38180$ & Arabidopsis thaliana & $A_{2} 338180$ & & $i$ \\
\hline $\mathrm{NqB77039}$ & Hypothedical proteia & AL 021889 & Arebidopsis thaliane & Alo21839 & & $i$ \\
\hline $\mathrm{NgC2179}$ & Hypothetical proteis & ACOOS170 & Arabidopsis thatiana & ACO0S170 & & $i$ \\
\hline NeC7035 & Bypotheticel proteis & Aliz12440 & Arabidopsis thaliane & At1z12440 & & 2 \\
\hline NeBu-98 & Bypodetical protein & AX647765 & Homo sapiens & At2201140 & & $i$ \\
\hline $\mathrm{Ng}_{\mathrm{BS} 257}$ & Hypestedical protecio & AL731629 & Oryza setiva & AY081836 & & 1 \\
\hline $\mathrm{N}_{\mathrm{R}} \mathrm{B} 6265$ & Byposteticel proteio & AtAg22820 & Arabidopsis thaliana & $A 14822820$ & & 1 \\
\hline $\mathrm{Ne} 22070$ & Bpoctetical protein & AtAg12040 & Arabidopsis thalliana & Af4g12040 & & $i$ \\
\hline
\end{tabular}

${ }^{a} \mathrm{NE}$, non-enzyme; Ox, oxidoreductase; $\mathrm{Tr}$, transferase; Hy, hydrolase; Ly, lyase; Is, isomerase; Lg, ligase. 
A

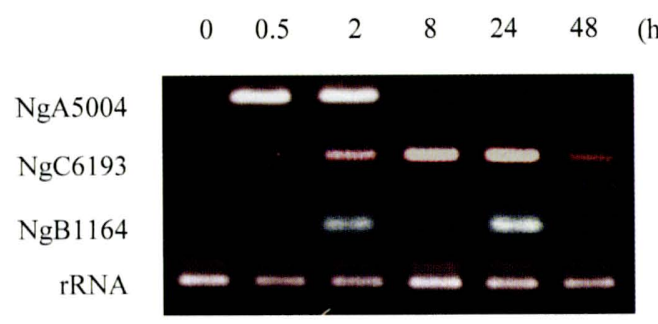

B
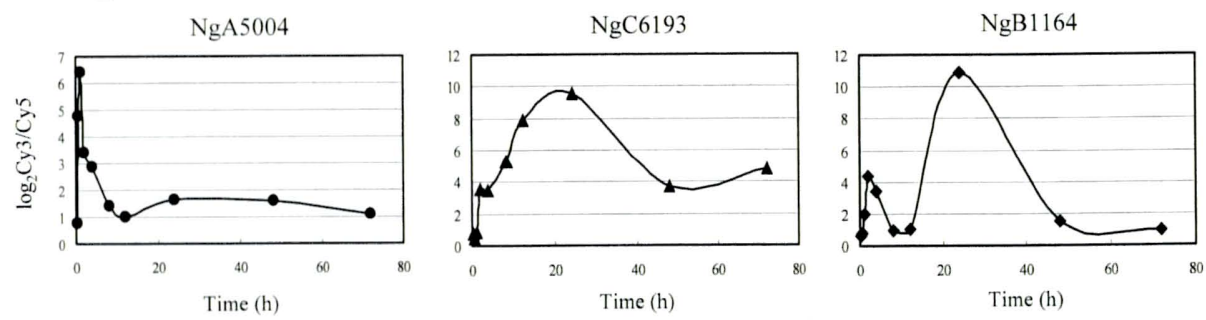

Fig. 4. Comparison of the microarray data and RT-PCR analysis for three selected genes

A, Total RNA from the $N$. glutinosa leaves at $0.5,2,8,24$, and $48 \mathrm{~h}$ after wounding were extracted and amplified, as described under Materials and methods. The $18 \mathrm{~S}$ rRNA at the bottom was done to serve as a total RNA control. B, Expression patterns of the three selected genes described from the microarray analysis were shown.

Materials and methods. Figure 5 illustrates a hierarchical clustergram of genes which were classified into 6 groups by related regulation patterns (correlation values $<0.85$ ). Obviously, it could be expected that genes identified by more than two clones are clustered in the same groups. For example, 8 putative chloroplast thiazole biosynthetic protein and 4 nsLTPs were perfectly classified into the same groups II and I, respectively. This result demonstrates the experimental reliability of our data obtained by the microarray analysis.

It is generally supposed that the early responsive genes are involved in a signal transduction for a specific expression of defense-related genes of plants. The transcripts of genes belonging to group VI began to accumulate as early as 10 min after wounding and disappeared after $1 \mathrm{~h}$. In addition, the transcripts of the genes included in groups $\mathrm{V}$ and IV began to accumulate $30 \mathrm{~min}$ after wounding, reached a maximum level within $1 \mathrm{~h}$ and gradually decreased during $4 \mathrm{~h}$ and $8 \mathrm{~h}$. Groups VI and V include several hypothetical protein genes. Although their translational products have not been characterized, they may play a role in a signal transduction for lately inducible expression of genes. In contrast to the early responsive expression of the genes included in groups VI and IV, the transcripts of the genes belonging to groups III, I, and II began to accumulate $4 \mathrm{~h}$ after wounding, and therefore these genes are considered to be late-responsive genes. These genes include those encoding heat shock proteins, non-specific lipid transfer proteins, and several enzymes, such as adenosine kinase and glutathione S-transferases. These 


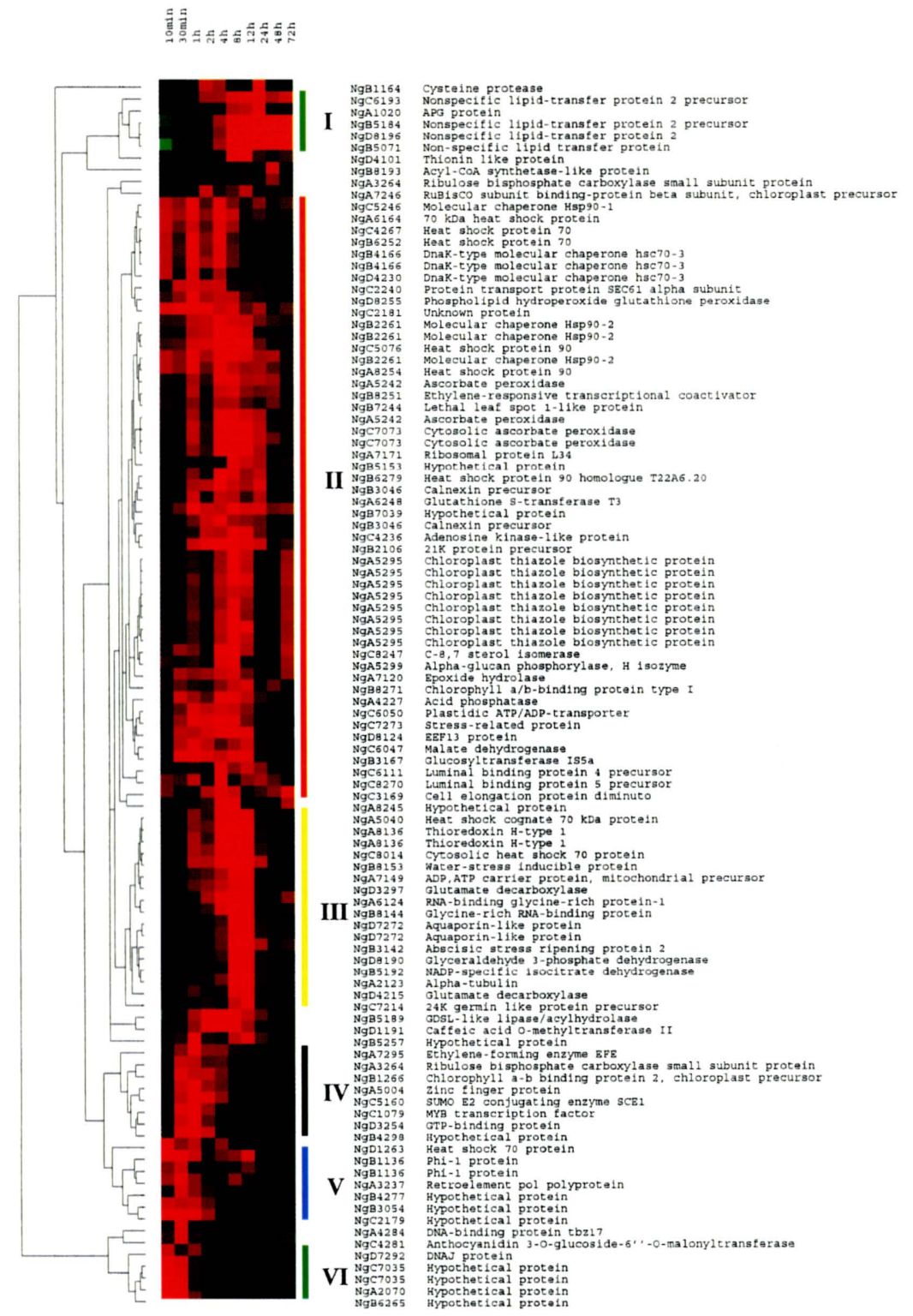

Fig. 5. Clustered display of data from the time course of mechanical wounding

A time course of wound-inducible gene expression in the $N$. glutinosa leaves was constructed using cDNA microarrays. For simplicity, only those genes for which the transcript levels changed substantially as a result of wounding are included. Genes were ordered using a clustering program (see Materials and methods) so that those with similar expression patterns would be grouped together. Each gene is represented by a single row of colored boxes, and each time point is represented by a single column. Induction (or repression) ranges from pale to saturated red (or green). 
translational products may serve as effecter proteins or enzymes in metabolisms or plant defense. A characteristic feature of the genes included in group II was to be induced twice in response to wounding. The first transcripts began to accumulate $1 \mathrm{~h}$ after wounding and decreased within $2 \mathrm{~h}$. Then, the second induction occurred and the transcripts reached a maximum at $4 \mathrm{~h}$ after wounding. This group predominantly includes genes encoding either heat shock proteins or molecular chaperones. Their translational products may play dual functions in defense reaction of the $N$. glutinosa leaves. In general, it could be expected that genes clustered in the same groups may be co-regulated by common transcriptional factors and also translational products belonging to the same clusters may share similar or related roles in defense toward wounding. Hence, further studies on the structure of the genes and their translational products will provide valuable insight into the molecular mechanism of defense response to wounding.

\section{Possible Translational Products}

In the present study, we screened wound-inducible genes in the $N$. glutinosa leaves by using cDNA microarray, and 86 genes were assigned as wound-inducible genes. Their possible translational products include 30 enzymes and 45 non-enzyme proteins, as given in Table 1. Among the enzymes, there are 8 oxidoreductases, 7 transferases, 8 hydrolases, 4 lyases, one isomerase and 2 ligases. It is known that cellular metabolism is altered by environmental stresses. For example, scavenger enzymes such as glutathione S-transferase and ascorbate peroxidase function as reactive oxygen species (ROS) elimination in condition of oxidative stress (Wagner et al., 2002; Yoshimura et al., 2000). Furthermore, several kinases and phosphatases are known to be involved in a signaling pathway for responsive induction of defense-related genes (Asai et al., 2002; Hailling et al., 2003). However, detailed analyses on the effects of stress on the majority of the enzymes in individual metabolic pathways are lacking. Hence, a high throughput analysis of the enzymes would lead to a better understanding of their defensive role in response to wounding.

As for non-enzyme proteins, many genes encoding heat shock proteins (HSPs) and molecular chaperones were identified as wound-inducible gene in the $N$. glutinosa leaves. While HSPs ostensibly function in the development of thermotolerance, their expression levels would be increased when the plant is subjected to other stresses such as water stress, heavy-metal toxicity and cold stress (Coca et al., 1996; Gyorgyey et al., 1991; Sabehat et al., 1998). Beside environmental stresses, HSP in plants is also synthesized in certain stages of development such as embryogenesis, germination, pollen development and fruit maturation (Gyorgyey et al., 1991; DeRocher and Vierling, 1995; Laurence et al., 1997; Wehmeyer et al., 1996). Arabidopsis sequencing project revealed many HSP-related genes (The Arabidopsis Genome Initiative, 2000), and they are classified into five groups, low molecular weight HSP, chaperonin, HSP70, HSP90, and HSP100 family. Chaperonin, HSP70, HSP90 and HSP100 were homologous to GroE, DnaK, HtpG, and ClpB in E. coli, respectively. In the $N$. glutinosa leaves, 13 HSP-related genes except HSP100 family were identified as up-regulated genes upon wounding. As described above, the genes encoding some HSPs are induced twice in response to wounding, and therefore, they may play essential roles in defense reaction in response to wounding.

Of 86 genes identified in this study, 15 genes including 11 hypothetical protein genes 
and one unknown protein gene were identified as wound-inducible genes. A further study on the wound-inducible genes identified in the present study and/or characterization of their translational products will provide valuable insight into the defense mechanism of plants.

As described above, $N$. glutinosa displays TMV-resistance mediated by $N$-gene at $25^{\circ} \mathrm{C}$, while TMV-infection at $35^{\circ} \mathrm{C}$ allows TMV to spread systemically and develop a characteristic mosaic phenotype that is visible approximately 10 days after infection. The present study demonstrated the dependability of the full-length cDNA microarray for a comprehensive analysis of extensive changes of the gene expression. Hence, the microarray analysis of the TMV-inducible genes in the $N$. glutinosa leaves at $25^{\circ} \mathrm{C}$ and $35^{\circ} \mathrm{C}$ would provide valuable information about the $N$-gene mediated disease resistance.

\section{REFERENCES}

Asai, T., Tena, G., Plotnilkova, J., Willman, M. R., Chlu, W. L. Gomez-Gomez, L., Boller, T., Ausubel, FM. and Sheen, J. 2002 MAP kinase signaling cascade in Arabidopsis innate immunity. Nature 415: 977-983

Cleveland, W. S. 1979 Robust locally weighted regression and smoothing expression measures and reproducibility in microarray assays. J. Amer. Stat, Assoc., 74: 829-836

Coca, M. A., Almoguera, C., Thomas, T. L., and Jordano, J. 1996 Differential regulation of small heat-shock genes in plants: analysis of a water-stress-inducible and developmentally activated sunflower promoter. Plant. Mol. Biol. 31: 863-876

De Bruxelles, G. L. and Roberts, M. R. 2001 Signals regulating multiple responses to wounding and herbivores. Crit. Rev. Plant Sci., 20: 487-521

DeRocher, AE. and Vierling, E. 1995 Cytoplasmic, HSP70 homologues of pea; differential expression in vegetable and embryonic organs., Plant Mol. Biol., 27: 441-456

Dubouzet, JG., Sakuma, Y., Ito, Y., Kasuga, M., Dubouzet, EG., Miura, S., Seki, K. and Yamaguchi-Shinozaki, K. 2003 OsDREB genes in rice, Oryza sativa L, encode transcription activators that function in drought-, high-salt- and cold-responsive gene expression. Plant J., 33: $751-763$

Eisen, M. B., Spellman, P. T., Brown, P. O., and Botstein, D. 1998 Cluster analysis and display of genome-wide expression patterns. Proc. Natl. Acad. Sci. USA, 95: 14863-14868

Fowler, S. and Thomashow, M. F. 2002 Arabidopsis transcriptome profiling indicates that multiple regulatory pathways are activated during cold acclimation in addition to the CBF cold response pathway. Plant Cell, 14: 1675-1690

Gong, Z., Koiwa, H., Cushman, M. A., Ray, A., Bufford, D., Kore-eda, S., Matsumoto, T. K., Zhu, J., Cushman, J. C., Bressan, R. A., and Hasegawa, P. M. 2001 Genes that are uniquely stress regulatory in salt overly sensitive (sos) mutants. Plant Physiol., 126: 365-75

Graham, J. S., Hall, G., Pearce, G., and Ryan, C. A. 1986 Regulation of synthesis of proteinase inhibitors I and II mRNAs in leaves of wounded tomato plants. Planta, 169: 399-405

Gyorgyey, J., Gartner, A., Nemeth, K., Magyar, Z., Hirt, H., Heberle-Bors, E., and Dudits, D. 1991 Alfalfa heat shock genes are differentially expressed during somatic embryogenesis. Plant. Mol. Biol. 16: 999-1007

Hailling, J., Yidong, L., Kwang, Y. Y., Chana, Y. K., Barbara, B., and Shuqun, Z. 2003 Function of mitogen-activated protein kinase pathway in $\mathrm{N}$ gene-mediated resistance in tobacco. Plant J. 33: $719-731$

Jameson, P. E. and Clarke, S. F. 2002 Hormone-virus interactions in plants. Crit. Rev. Plant Sci., 21: 205-228

Julich, A. 1995 Implementations of BLAST for parallel computers., Comput. Appl. Biosci., 11: 3-6

LaFayette, P. R., Nagao, R. T., O'Grady, K., Vierling, E., and Key J. L. 1996 Molecular characterization of cDNAs encoding low-molecular-weight heat shock proteins of soybean. Plant Mol. Biol., 30: $159-169$ 
Laurence, S. D., Cline, K., and Moore, G. A. 1997 Chromoplast development in ripening tomato fruit; identification of cDNA for chromoplast-targeted proteins and characterization of a cDNA encoding a plastid-localized low-molecular-weight heat shock protein. Plant Mol. Biol., 33: 483-492

Oztur, ZN., Talama, V., Deyholos, M., Michalowski, CB., Galbraith, DW., Gozukirmizi, N., Tuberosa, R., and Bohnert, HJ. 2002 Monitoring large-scale changes in transcript abundance in drought- and salt-stressed barley. Plant Mol. Biol., 48: 551-573

Reymond, P. and Farmer, E. E. 1998 Jasmonate and salicylate as global signals for defense gene expression. Curr, Opin. Plant Biol., 1: 404-411

Ryan, C. A. 1990 Protease inhibitors in plants: Genes for improving defenses against insects and pathogens. Annu. Rev. Phytopathol., 28: 245-249

Sabehat, A., Lurie, S., and Weiss, D. 1998 Expression of smallheat-shock proteins at low temperatures. Plant Physiol. 117: 651-658

Seki, M., Narusaka, M., Ishida, J., Nanjo, T., Fujita, M., Oono, Y., Kamiya, A. Nakajima, M., Enju, A., Sakurai, T., Satou, M., Akiyama, K., Taji. T., Yamaguchi-Shinozaki, K., Carninci, P., Kawai, J., Hayashizaki, Y., and Shinozaki, K. 2002 Monitoring the expression profiles of 7000 Arabidopsis genes under drought, cold and high-salinity stresses using a full-length cDNA microarray. Plant J., 3: 279-292

Seki, M., Narusaka, M., Abe, H., Kasuga, M., Yamaguchi-Shinozaki, K., Carninci, P., Hayashizaki, Y., and Shinozaki, K. 2001 Monitoring the expression pattern of 1300 Arabidopsis genes under drought and cold stresses by using a full-length cDNA microarray. Plant Cell, 13: 61-72

Shirzadegan, M., Christie, P., and Seemann, J. R. 1991 An efficient method for isolation for RNA from tissue cultured plant cells. Nucleic Acids Res., 11: 6055

Suzuki, Y. and Sugano, S. 2001 Construction of full-length-cDNA libraries. The oligo-capping method. Methods Mol. Biol., 175: 143-153

The Arabidopsis Genome Initiative, 2000 Analysis of the genome sequence of the flowering plant Arabidopsis thaliana. Nature, 408: 796-815

Wagner, U., Edwards, R., Dixon, D. P., and Mauch, F. 2002 Probing the diversity of the Arabidopsis glutathione $S$-transferase gene family. Plant Mol. Biol. 49: 515-532

Wehmeyer, N., Hernandez, L. D., Finhelstein, R. R., and Vierlig, E. 1996 Synthesis of small heat-shock proteins in part of the developmental program of late seed maturation. Plant Physiol., 112: 747-757

Whitham, S., Dinesh-Kumar, S. P., Choi, D., Hehl, R., Corr, C., and Baker, B. 1994 The product of the tobacco mosaic virus resistance gene $\mathrm{N}$ : similarity to toll and the interleukin-1 receptor. Cell, 78: 1101-1115

Yoshimura, K., Yabuta, Y., Ishikawa, T., and Shigeoka, S. 2000 Expression of spinach ascorbate peroxidase isoenzymes in response to oxidative stresses. Plant Physiol. 123: 223-234

Zinselmeier, C., Sun, Y., Helentjaris, T., Beatty, M., Yang, S., Smith, H., and Habben, J. 2002 The use of gene expression profiling to dissect the stress sensitivity of reproductive developmental in maize. Field Crop Res., 75: 111-121 